\title{
Bank Failure Prediction Model Based on Governance: A Case of Rural Banks in Indonesia
}

\author{
Suwandi ${ }^{1}$, Noer Azam Achsani ${ }^{1}$, Dedi Budiman Hakim ${ }^{2} \&$ Halim Alamsyah ${ }^{3}$ \\ ${ }^{1}$ School of Business, IPB University (Bogor Agricultural University), Bogor, Indonesia \\ ${ }^{2}$ Faculty of Economics and Management, IPB University (Bogor Agricultural University), Kampus IPB \\ Dramaga Bogor, Indonesia \\ ${ }^{3}$ Indonesia Deposit Insurance Corporation, Equity Tower Lt. 20-21, SCBD, Jl. Jend. Sudirman Kav.52-53, \\ Jakarta, Indonesia \\ Correspondence: Suwandi, School of Business, IPB University (Bogor Agricultural University), Bogor 16151, \\ Indonesia. E-mail: miskaksuwandi@yahoo.com
}

Received: August 16, 2019

doi:10.5539/ass.v15n10p49
Accepted: September 6, 2019

Online Published: September 29, 2019

URL: https://doi.org/10.5539/ass.v15n10p49

\begin{abstract}
Since it was first operating in 2005 until 2017, Indonesia Deposit Insurance Corporation (IDIC) has liquidated 91 rural banks which were determined as failed banks by supervision authority. The cause of the failing of the bank is mainly due to the incapability of the bank to meet the minimum Capital Adequacy Ratio (CAR). Bank's capital was shrunk by the loss caused by fraud. The fraud is mostly induced by the lack of good corporate governance implementation. By using the logistic regression, it can be concluded that (1) the incomplete of responsibility letter which will be used in the event of bank failure, submitted by the bank commissioners; (2) the incomplete of responsibility letter which will be used in the event of bank failure, submitted by the bank directors; (3) role duplication between shareholders and board of directors; and (4) bank had classified as special supervision, have impact on the increase of rural banks failure. At the same time, the compliance level of rural banks to a correct premium payment has impacted to decrease of rural banks failure possibilities.
\end{abstract}

Keywords: CAR, failed bank, fraud, good corporate governance, logistic model, stepwise

\section{Introduction}

The Financial crisis has happened since centuries and keeps repeating its occurrence in a different period and location. Financial, economic, and banking crisis which took place in 1930 has located in the United States of America (USA) which was widely known as "the great depression". Furthermore, some countries in South East Asia region such as Indonesia, Thailand, Malaysia, Philippines, and Korea had also experienced an economic and financial crisis in 1997-1998, where there were a massive bank runs and economic deterioration. In 2008, a global financial crisis had made a comeback and was triggered by a financial crisis that hit the USA and spread worldwide, including Indonesia, which was impacted by the global financial crisis. Kaminsky and Reinhart (1999) mentioned that there is connectivity between the banking crisis and currency crisis, which then led to a deeper banking crisis. As a result of the global financial crisis, a deposit insurance corporation was established in many countries.

Lately, the total number of banks who operate in Indonesia, both commercial and rural banks/Islamic rural banks has been declining. From 2012 to 2017, the IFSA recorded a total number of commercial banks at the end of 2017 of 115 banks, decreasing by $4.1 \%$ from 2017 with a total of 120 banks. On the contrary, the total number of rural banks/Islamic rural banks decreased quite significantly, as shown in Table 1.

Table 1. Total Number of rural banks/islamic rural banks

\begin{tabular}{ccccccc}
\hline Group of Bank & Dec 2012 & Dec 2013 & Dec 2014 & Dec 2015 & Dec 2016 & Dec 2017 \\
\hline Number of rural banks/islamic rural banks & 1,825 & 1,794 & 1,800 & 1,800 & 1,794 & 1,729 \\
\hline Source: IFSA, processed (2017) & & & & & &
\end{tabular}

The decline of rural banks/Islamic rural banks was mainly caused by merger/acquisition, self-liquidation, and 
bank failure, which led to liquidation by IDIC.

Since IDIC was operated in 2005 until 2017, IDIC liquidated 84 rural banks/islamic rural banks.

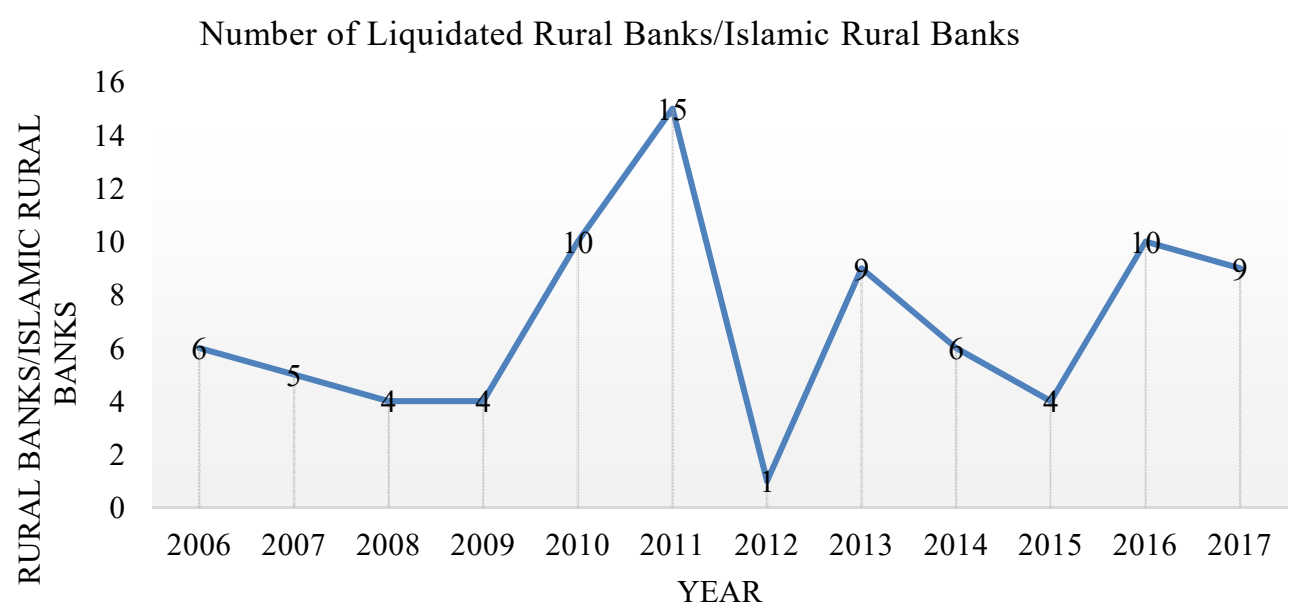

*) Exluding 2 rural banks/islamic rural banks that self-liquidated

Source: IDIC, processed (2018)

Figure 1. Number of Liquidated Rural Banks/Islamic rural banks

Refer to study conducted by IDIC in 2016, the main cause of the liquidated rural banks/Islamic rural banks was due to the fraud done by the owner, the management as well as the staff of the bank. The findings found by IDIC regarding the fraud are fake loans distribution, payment of loans instalments taken by the staff, withdrawal of deposits without depositors' consent, and uncollateralized deposits. For the study, IDIC used 71 liquidated rural banks/Islamic rural banks as at the end of 2016 as the sample of the research. As can be seen in Table 2, IDIC has noted 244 cases of frauds within the rural banks/Islamic rural banks.

Table 2. Causes of Bank Failures (2006-2016)

\begin{tabular}{|c|c|c|c|}
\hline No. & Causes of Fraud & Number & Total Losses (Million IDR) \\
\hline 1 & Misuse of loans & 73 & 807,104 \\
\hline 2 & Non-Performing Loans, Coll. Engineering, and Provision for loan losses & 62 & 87,631 \\
\hline 3 & Correction on collateral appraisal & 10 & 7,183 \\
\hline 4 & Violation in Loans Limit & 7 & - \\
\hline 5 & Use of RRA, Losses, and Embezzlement & 37 & 37,065 \\
\hline 6 & Liquidity shortage & 5 & 4,076 \\
\hline \multirow[t]{2}{*}{7} & Misuse of deposits & 45 & 209,208 \\
\hline & Total & 244 & $1,152,342$ \\
\hline
\end{tabular}

Source: IDIC Research (LPS), processed (2017)

Before frauds are found by the bank supervisors, the financial report is unable to well-describe the real condition of a bank. Thus the CAR that is calculated according to the report can't reflect the solvency level of the bank. Consequently, the use of CAR as a variable in predicting the failure of rural banks/Islamic rural banks is unreliable. A weak good corporate governance implementation can result in the occurrence of fraud. For this reason, this research will conduct a test on several variables as a proxy of the weakness of the good corporate governance implementation, which impacted the probability of rural banks/Islamic bank failures.

\section{Theoretical Basis}

\subsection{Theory of Bankruptcy}

Research on corporate bankruptcy was started by Beaver (1996) and Altman (1968). The research was used the accounting data from the balance sheet and income statement of a manufacturing company such as the financial ratios as discriminatory and prediction bankruptcy variables. Beaver (1996) used a single variable within the 
period of 1954-1964. As much as 30 financial ratios were grouped into cash flow ratios, net income ratios, debt to total asset ratios, liquid asset to total asset ratios, liquid asset to current debt ratios, and turnover ratios. There were six financial ratios which then selected as to be analysed variables. The research result showed those six financial ratios variables univariately can classify between a bankrupt and non-bankrupt company for 1 to 5 years beforehand. Cash flow/total liabilities is proven to be the best predictor. According to the research, one year before it went bankrupt, there is $13 \%$ of misclassification. The closer it is to bankruptcy, the level of misclassification is smaller.

Bankruptcy prediction by using the multivariate model was introduced by Altman (1968). The sample used for the model was 33 bankrupt manufacturing companies in the USA and 33 non-bankrupt companies within the period of 1946 to 1966.

Outtecheva (2007) describes that a company bankruptcy is a process. It started with early impairment due to the declining of asset quality, followed by the deteriorating of performance which led to cash flow problem, so that the company is failed to meet its short-term and long-term liabilities. In a certain condition, the asset value of a company can't meet all liabilities, which means the company has negative equity. In that condition, the company is declared as insolvent and goes to a bankrupt. The process of financial distress is shown in Figure 2 as follows.

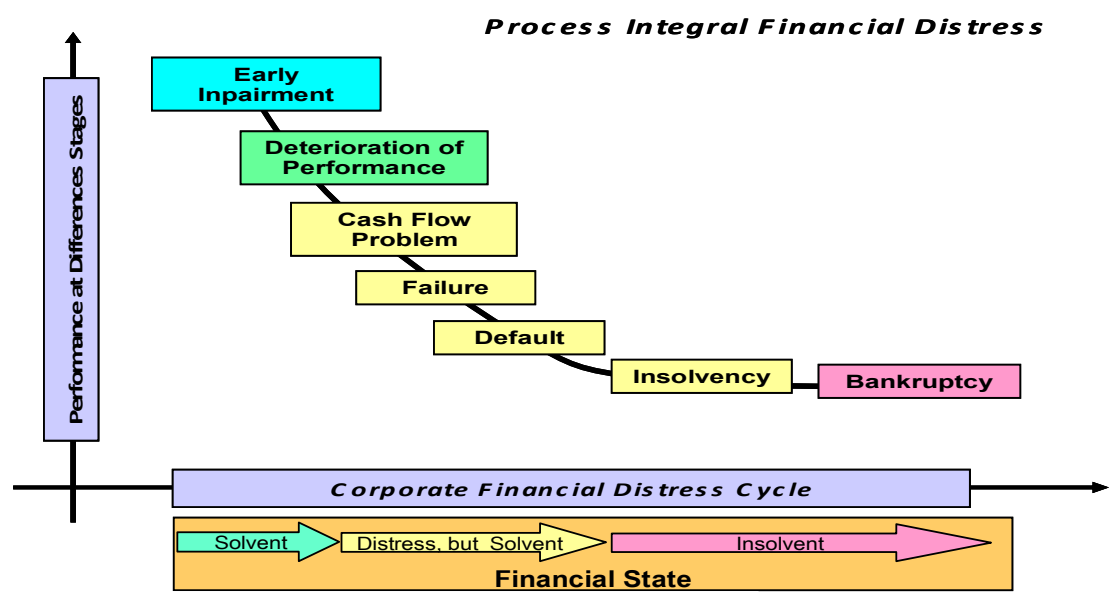

Source: Pranowo (2010), modified from Outtecheva (2007)

Figure 2. Financial Distress Process

As seen in Figure 2 of a company bankruptcy process, the company will at first experience a liquidity problem which further give an opportunity to the the inability of a company to operate well causing a bankruptcy to the company.

\subsection{Bank Soundness Level}

Generally, the level of bank soundness is measured by CAMEL (Capital, Assets, Management, Earnings, and Liquidity). In Indonesia, the measurement of bank soundness level is regulated in the Law No. 10 Year 1998 concerning Banking that a bank is obliged to maintain its bank soundness level which includes solvency, asset quality, management, income quality, liquidity, and sensitivity to the market. Moreover, the Law No. 10 Year 1998 concerning Banking stipulated that in a case a bank has problems that threaten its operation, Bank Indonesia can take any necessary measures such as requesting shareholders to inject more capital. In the Elucidation of the Law, a bank is deemed as having problems that threaten its business operations when according to the assessment made by Bank Indonesia, the business condition of the bank is deteriorating which was indicated by the decline in capital, assets quality, liquidity, profitability, as well as imprudent bank management that not comply with good corporate governance and prudential banking principles.

Bank Indonesia Regulation No.13/1/ PBI/2011 concerning Evaluation of Commercial Bank Soundness Levels affirms that banks are required to assess the soundness of banks individually using a Risk-Based Bank Rating approach with a range of assessments of risk profile factors; good corporate governance (GCG); profitability (earnings); and capital. Assessment of risk profile factors is an assessment of inherent risk and the quality of risk management implementation in bank operations against 8 (eight) risks, namely (1) credit risk; (2) market risk; (3) liquidity risk; (4) operational risk; (5) legal risk; (6) strategic risk; (7) compliance risk; and (8) reputation risk. 
Assessment of the GCG factor is an assessment of the implementation of GCG principles. Assessment of earnings factors includes an assessment of earnings performance, earnings sources, and earnings sustainability.

Soundness level assessment for rural banks/Islamic rural banks is referred to the Decree of Bank Indonesia Directors No. 30/12/KEP/DIR on 30 April 1997 and Bank Indonesia Regulation No. 9/17/PBI/2007 on 4 December 2007. There are 5 aspects that are assessed in the rural banks/Islamic rural banks soundness level assessment, i.e. (1) capital (risk-based capital to weighted assets ratio); (2) quality of productive assets (ratio of productive assets to provision for loans losses); (3) management (management in general and risk management); (4) profitability (ratio of profit to the average of business volume and ratio of operating expenses to the operating income); (5) liquidity (ratio of liquid instruments to liquid liabilities and ratio of loans to collected fund).

\section{Literature Review}

Konstituanto (2012) conducted research on the probability of bank failure in Indonesia from the management and financial aspects. The result of the research shows that the Merton model can well reflect the high probability level of commercial bank failure in Indonesia, which was caused by the lack of efficiency in bank management. Other research on bankruptcy by using the Merton model was done by Wibowo (2017) who looked at the method in measuring the bank bankruptcy probability and analysed its correlation of diversification of sources of income, Indonesian banking case. The research shows that the Merton model can illustrate the probability of banking failure in Indonesia which was influenced by the income diversification by using data of stock prices in the banking industry in Indonesia within the period of 2010-2015.

Ozili (2017) conducted research with a sample of 231 banks in Europe within the period of 2004-2014. The data used in this research was a GDP taken from the World Economic Forum. Ozili found that (1) the banks in Europe are using fee income indicator to support the company profit, either for banks with little chance of failure or for banks with higher chance of failure; (2) there is a positive correlation between interest income and non-interest income which indicates a systematically higher risk because of less of diversification benefits; (3) fee income on small banks is procyclical with a fluctuating economic condition, but not for big banks; (4) earning management can increase the income significantly depended on the size of banks in Europe post-crisis era. Cole and White (2012) have also done a research to find out the reasons of 117 out of 265 commercial banks failed during the crisis in 2009 with a logit regression model. The biggest chance of failure has occurred to the bank who allocated higher loans for development, commercial mortgages, and multi-family mortgages. Other findings showed that a bank who has a bigger allocation to security investment has a smaller chance of failure.

Ekinci and Erdal (2016) conducted research to predict failure of banks with a sample of 37 banks in Turkey. The research used 35 financial ratios based on capital, asset quality, management, income, liquidity, and sensitivity ratio of the CAMELS system. Conventional system used had created models such as ensemble learning model and hybrid ensemble learning model. The result of the research shows that the prediction level improved based on classification, sensitivity, specificity, and areas under the ROC (Return on Capital) curve by using the hybrid ensemble learning model, and the model concluded that it could be used to predict the bank failure in Turkey.

Calabrese and Giudici (2015) did research in predicting a bank failure by suggesting a new model based on macroeconomics and microeconomics factors. The research was done to banks in Italy. It is done by applying a regression model for binary data based on the extreme value theory, which generates a more effective value than the classic logistic regression model. It is caused by the use of information in the tail of default distribution. The research shows that microeconomics factor, which includes in the capital regulation, is significantly able to define the inaccurate failure manner, while macroeconomics factor can be of influence relevantly when the failure is not only occurred in default manner but also in terms of merger and acquisition. In this case, an extreme value theory-based model has a higher predictive value than classic logistic regression.

Bani, Zadehbagher, and Saberimanesh (2014) have conducted research on bank failure in Iran. Data used was 17 commercial and private banks in Iran from 2008 to 2012. The research result indicates that Zmisky Model can predict more of the failure of banks in Iran than Toffler model, which is more conservative. The analysis of failure prediction is generally done for investment decision for the investors in Iran by taking into account the unpaid principal and interest risk on capital to a minimum level.

Bashir, Javed, and Iqbal (2015) were done research on business failure in Karachi money market using the Altman Z-Score model. Data used for this research was company data of 124 listed companies in Karachi (Pakistan) Stock Exchange, by taking into account the variable of financial indicator related to the company financial soundness assessment during the period of 2010-2012. The result of the McNemar test and Kappa test demonstrated a significant relation of the real status of the company and the prediction status on the default of the company. So, the Altman Z-score model is the best prediction tools for research on companies in Pakistan 
and the significance level of the Altman model in predicting the failure and non-failure of the bank reached $81 \%$.

Rosa and Gartner (2017) conducted research to suggest an early warning model in predicting financial distress in banking institutions in Brazil. The research model used for the research was the multivariate logistics regression, with an independent variable of financial indicators such as capital adequacy, assets quality, management quality, income, and liquidity. The result was evaluated based on the estimation of the in-sample parameter, out-of-sample test, and all variable altogether, which had a positive significance level of $81 \%, 94 \%$, and $89 \%$. In conclusion, specific balance sheet indicators are relevant for early warning system of financial pressures in Brazil banks, which contribute to the literature on intermediary credit risk, especially from the banking supervisory perspectives who acts in supporting the financial stability.

Wilopo (2006) also did research on bank bankruptcy prediction using the CAMEL model, Log. Assets, and dummy with a sample of 235 banks at the end of 1996. The research shows that in overall the prediction level of variables used in the research was high (more than $50 \%$ as the cut off value), nevertheless there was a mistake that the prediction power of liquidated banks was $0 \%$ because of all liquidated banks sample, all were predicted to be unliquidated. It can be concluded that the failure of banks in Indonesia could not be predicted perfectly if only utilizing the CAMEL model.

Kusdiana (2014) did a research on 31 banks which consist of 4 Enterprise Banks, 21 Forex National Private Commercial Banks, 3 Non-forex National Private Commercial Banks, 1 Regional Development Commercial Banks, and 2 Mixed Banks. Research techniques used in this research were descriptive analysis, Altman's Z-score model analysis, and Logistic Regression. The research shows that the analysis used to predict the bankruptcy by using the Altman Z-score model could predict the failure of a bank better than the CAMEL model with a high bankruptcy probability level.

Jan and Marimuthu (2016) analyse the bankruptcy profile of foreign Islamic banks versus domestic Islamic banks that operated in Malaysia during the subprime financial crisis in 2007-2008 and triggered the bankruptcy evaluation for the banking industry which became vital. The research shows that for foreign Islamic banks, $40 \%$ of them were in the bankruptcy zone, $40 \%$ of the banks were in the grey zone, and $20 \%$ of the banks were in the safe zone. Meanwhile, for domestic Islamic banks, $75 \%$ of the banks were in the bankruptcy zone, $0 \%$ of the banks in the grey zone, and $25 \%$ of the banks in a safe zone.

Slefendorfas (2016) had done research towards 145 companies (73 bankrupt companies and 73 going concern companies). The research model used was the multivariate discriminant analysis and ZGS linear function. In the analyzing process, 156 financial ratios correlated between the bankrupt companies and going-concern companies and also used the Mann-Whitney $U$ technique. The research shows that $89 \%$ of the companies are well-classified, which means that the model is strong enough to predict the bankruptcy probability of listed private companies both bankrupt and going concern companies in Lithuania.

\section{Research Method}

\subsection{Research Data}

Data used to see the impact of GCG implementation on the failure of rural banks/islamic rural banks was all rural banks/Islamic rural banks which have been in operation in Indonesia as of 31 December 2018, including the rural banks/Islamic rural banks that were liquidated by the IDIC since it was first operated in 2005 with a total of 1,915 banks. The proxy data of GCG implementation were (1) the segregation of the roles of shareholders, directors, and board of commissioners; (2) the compliance level of bank in fulfilling the requirements of deposit insurance program of IDIC, such as the compliance in the premium payment of IDIC and compliance in submitting the responsibility letter in the time of bank failure.

IDIC noted that of 1,915 rural banks/Islamic rural banks (that had been in operations), there are 184 banks were classified as in special supervision, and 91 banks had their license revoked. Based on the research conducted by the IDIC, there were frauds within the rural banks/Islamic rural banks, which were caused by the negligence to the good corporate governance, as shown in Table 3.

Table 3. Implementation of GCG in Rural Banks/Islamic rural banks (2006-2017)

\begin{tabular}{llccc}
\hline No & Description & Total Bank*) & $\begin{array}{c}\text { Bank Under Special } \\
\text { Supervision }\end{array}$ & $\begin{array}{c}\text { Failed } \\
\text { Bank }\end{array}$ \\
\hline & Population & $\mathbf{1 , 9 1 5}$ & $\mathbf{1 8 4}$ & $\mathbf{9 1}$ \\
1 & Shareholders Acting as Directors & $278(15 \%)$ & $28(15 \%)$ & $20(22 \%)$ \\
2 & Shareholders Acting as Commissioner & $854(475)$ & $102(55 \%)$ & $48(53 \%)$ \\
\hline
\end{tabular}




\begin{tabular}{|c|c|c|c|c|}
\hline 3 & Directors Acting as Commissioner & $30(2 \%)$ & $2(1 \%)$ & - \\
\hline 4 & $\begin{array}{l}\text { Non-compliant to the premium payment for the last } 5 \text { years } \\
\text { before classified as bank in special supervision (total) }\end{array}$ & $177(9 \%)$ & $41(22 \%)$ & $26(29 \%)$ \\
\hline 5 & $\begin{array}{l}\text { Non-compliant to the premium payment for the last } 5 \text { years } \\
\text { before classified as bank in special supervision (time) }\end{array}$ & $553(29 \%)$ & $97(53 \%)$ & $55(60 \%)$ \\
\hline 6 & $\begin{array}{l}\text { Incomplete submission of responsibility letter in the event of } \\
\text { bank failure by the Directors }\end{array}$ & $80(4 \%)$ & $39(21 \%)$ & $34(37 \%)$ \\
\hline 7 & $\begin{array}{l}\text { Incomplete submission of responsibility letter in the event of } \\
\text { bank failure by the Boards }\end{array}$ & $104(4 \%)$ & $48(26 \%)$ & $40(44 \%)$ \\
\hline 8 & $\begin{array}{l}\text { Incomplete submission of responsibility letter in the event of } \\
\text { bank failure by the Controlling Shareholders }\end{array}$ & $916(48 \%)$ & $120(65 \%)$ & $55(60 \%)$ \\
\hline 9 & $\begin{array}{l}\text { Incomplete submission of responsibility letter in the event of } \\
\text { bank failure by the Directors \& Boards }\end{array}$ & $48(3 \%)$ & $28(15 \%)$ & $28(31 \%)$ \\
\hline 10 & $\begin{array}{l}\text { Incomplete submission of responsibility letter in the event of } \\
\text { bank failure by the Directors \& Controlling Shareholders }\end{array}$ & $56(3 \%)$ & $35(19 \%)$ & $31(34 \%)$ \\
\hline 11 & $\begin{array}{l}\text { Incomplete submission of responsibility letter in the event of } \\
\text { bank failure by the Boards \& Controlling Shareholders }\end{array}$ & $73(4 \%)$ & $41(22 \%)$ & $36(40 \%)$ \\
\hline 12 & $\begin{array}{l}\text { Incomplete submission of responsibility letter in the event of } \\
\text { bank failure by the Directors, Boards, and Controlling } \\
\text { Shareholders }\end{array}$ & $38(2 \%)$ & $26(14 \%)$ & $26(29 \%)$ \\
\hline
\end{tabular}

Source: IDIC Data, processed (2018)

*) Total rural bank/Islamic rural bank that has/had been operating in Indonesia.

Table 3 shows that of 1,915 rural banks/islamic rural banks, as many as 132 rural banks/islamic rural banks (72\%) were classified as in special supervision and 94 rural banks/islamic rural banks (51\%) were classified as failed banks had role duplications. The Table 3 also shows that there were many troubled rural banks/islamic rural banks (both in special supervision and failed bank) had a high non-compliant level to the regulations with a proxy of regulations on deposit insurance program by IDIC.

\subsection{Analytical Tools}

The model used to find out the impact of GCG implementation on the failure of rural banks/Islamic rural banks was the logit model. The logit model is a non-linear regression model that formulated an equation where the dependent variable is categorical in nature. The basis of the model creates binary values such as 0 and 1 . The figure created represents a particular category which was derived from the calculation of the probability of occurrence for each category.

Table 4. Logit Model Probability

\begin{tabular}{ccc}
\hline$Y_{i}$ & Probability \\
\hline 0 & $1-P_{i}$ \\
& $P_{i}$ \\
Total & 1 \\
\hline
\end{tabular}

Source: Gujarati (2003)

The main objective using the logistic regression analysis in this research is to predict the probability of event (bank in special supervision) occurrence based on the existing predictive value (independent variable).

\subsection{Research Techniques}

In the attempts of finding out the impact of GCG implementation to the failure of rural banks/islamic rural banks, identification on the governance elements which significantly affect the failure of rural banks/islamic rural banks was done. The proxy of the GCG implementation were (1) the segregation of roles of shareholder, commissioner, and director; and (2) compliance level of rural banks/islamic rural banks in fulfilling the requirements of deposit insurance program such as compliance in the premium payment and compliance in the submission of the responsibility letter by the controlling shareholder, commissioner, and/or director. The variables were taken by considering the findings of IDIC review (2016) that the leading cause for the failure of rural banks/islamic rural banks is fraud done by the owners, commissioners and (or) directors. Some rural banks/islamic rural banks have a role duplication between the owner and commissioner, owner and director, or owner, commissioner and director. Moreover, the findings reveal that in several rural banks/islamic rural banks, the controlling shareholder, 
commissioner, and (or) director did not submit the responsibility letter.

Based on the above consideration, GCG elements took as variables to be tested as follows:

a. Double position as shareholders and also as the boards;

b. Double position as shareholders and directors;

c. Double position as boards and directors;

d. Non-compliant in the premium payment in terms of the total amount and the due date time;

e. Non-compliant in the submission of the responsibility letter in the event of failure of rural banks/Islamic rural banks by the directors, boards, and controlling shareholders.

As previously elaborated that the analysis of the impact of GCG implementation to the failure of rural banks/islamic rural banks used several independent variables, such as:

a. Double position as shareholders and directors (X1)

The variable reflects the role of concurrent position as shareholders and directors. The variable was taken into account to see the impact on the concurrent position to the failure of rural banks/islamic rural banks. As we all know that some directors, all rural banks/islamic rural banks are also the shareholders. This variable is taken to see how the effect of concurrent position in the failure of rural banks/islamic rural banks. As is known, that some members of the rural banks/islamic rural bank's board of directors are from shareholders. Similar to the duplication of the roles of shareholders and boards, this roles duplication is also affecting the effectivity of GCG implementation because it can induce the conflict of interest.

b. Double position as shareholders and commissioner (X2)

The variable describes the role of concurrent position as shareholders and board members. The variable was taken into account to see the impact on the duplication of the roles to the failure of rural banks/islamic rural banks. Some board members of all rural banks/islamic rural banks are also the shareholders. The duplication of roles has undoubtedly affected the effectivity of GCG implementation because the role and responsibility between the shareholders and boards is different.

c. Compliant in the premium payment in the correct amount (X3)

The variable illustrates the level of compliance of rural banks/islamic rural banks in paying the premium in the correct amount. The variable was taken to see whether the level of bank compliance in paying the premium in the correct amount correlates with the level of rural banks/islamic rural banks failure. The premium is calculated at $0.01 \%$ of the deposits average within one semester. The period for the research was for the premium payment within the last five years.

\section{d. Compliant in the premium payment in a timely manner (X4)}

Similar to the variable of compliant in premium payment in the accurate amount, this variable describes the level of compliant of rural banks/islamic rural banks in premium payment in a timely manner, According to Article 12 of IDIC Law, the premium payment for period I is due on January 31st at the latest and for the period II, it is due on July 31 st at the latest. The variable was taken to see whether the level of compliant of the bank in paying the premium in a timely manner has a correlation in the level of rural banks/islamic rural banks failure. The premium payment period analysed was within the last 5 years period.

\section{e. Responsibility letter of directors (X5)}

The directors are also obliged to submit the statement letter according to the Article 9 of IDIC Law which include information on (i) commitment and willingness to comply with all requirements as stipulated in the IDIC regulation; (ii) willingness to hold accountable personally of any negligence and/or any legal violating acts that incur the loss and threaten the business of the bank; (iii) willingness to release and hand over the rights, ownership, management, and/or interests to IDIC in the event of failure of the banks which was then decided to be rescued or liquidated. The letter was submitted soon after the bank became a member of the deposit insurance program of IDIC. The variable was taken to see the level of compliance of the bank to the deposit insurance program of IDIC.

\section{f. Responsibility letter of the commissioners (X6)}

Similar to the controlling shareholders, the board member is obliged to submit the statement letter according to the Article 9 of IDIC Law which include information on (i) commitment and willingness to comply with all requirements as stipulated in the IDIC regulation; (ii) willingness to hold accountable personally of any 
negligence and/or any legal violating acts that incur the loss and threaten the business of the bank; (iii) willingness to release and hand over the rights, ownership, management, and/or interests to IDIC in the event of failure of the banks which was then decided to be rescued or liquidated. The letter was submitted soon after the bank became a member of the deposit insurance program of IDIC. The variable was taken to see the level of compliance of the bank to the deposit insurance program of IDIC.

g. Responsibility letter of the controlling shareholders (X7)

According to Article 9 of IDIC Law, the controlling shareholders are obliged to submit a statement letter which include information on (i) commitment and willingness to comply with all requirements as stipulated in the IDIC regulation; (ii) willingness to hold accountable personally of any negligence and/or any legal violating acts that incur the loss and threaten the business of the bank; (iii) willingness to release and hand over the rights, ownership, management, and/or interests to IDIC in the event of failure of the banks which was then decided to be rescued or liquidated. The letter was submitted soon after the bank became a member of the deposit insurance program of IDIC. The variable was taken to see the level of compliance of the bank to the deposit insurance program of IDIC.

h. Had classified as the bank in the special supervision (X8).

The variable reflected whether the banks had classified as a bank in special supervision tend to become a failed bank. As mentioned earlier, there were rural banks/islamic rural banks that were classified as banks in special supervision for five times, before being announced as failed banks.

In this research, the logit regression formula that will be developed is:

$$
\begin{gathered}
P_{\mathrm{i}}=\frac{1}{1+e^{-Z i}} \\
\operatorname{Ln}\left(P_{i}\right)=Z_{i}=\beta_{0}+\beta_{1} X_{1}+\beta_{2} X_{2}+\beta_{3} X_{3}+\beta 3 X 3+\beta_{4} X_{4}+\ldots+\beta_{8} X_{8}
\end{gathered}
$$

whereas:

$P_{\mathrm{i}} \quad$ : Probability of rural banks/islamic rural banks failure.

$X_{1}$ : Shareholder acting as director $(1=\mathrm{yes}, 0=\mathrm{no})$.

$X_{2}$ : Shareholder acting as commissioner (1=yes, $0=$ no).

$X_{3}$ : Compliant to the premium payment in the correct amount within the last 5 years ( $1=$ not comply, $0=$ comply).

$X_{4}$ : Compliant to the premium payment in a timely manner within the last 5 years ( $1=$ not comply, $0=$ comply).

$X_{5}$ : Directors submit the responsibility letter in the event of rural banks/Islamic rural banks failure (1=incomplete, $0=$ complete).

$X_{6}:$ Commissioners submit the responsibility letter in the event of rural banks/Islamic rural banks failure (1=incomplete, $0=$ complete).

$X_{7}$ : Shareholders submit the responsibility letter in the event of rural banks/Islamic rural banks failure (1=incomplete, $0=$ complete).

$X_{8} \quad$ : Bank had classified as bank in special supervision ( $\left.1=\mathrm{yes}, 0=\mathrm{no}\right)$.

$\beta_{0}:$ Constant.

$\beta_{i}:$ Slope coefficient of independent variable.

\section{Results and Discussions}

Even though the logit probabilistic model was the model that finally been chosen to be used in the research, there was a need for filtering the independent variables that were going to be used in the estimation of logit equation to enable the independent variables to clearly define the dependent variables. The filtering process of dependent variables was done through stepwise regression model with the result only 5 variables were through as predictor which are double position as shareholders and directors $\left(X_{1}\right)$; responsibility letter of directors $\left(X_{5}\right)$; responsibility letter of the commissioners $\left(X_{6}\right)$; and bank had classified as bank in special supervision $\left(X_{8}\right)$, have positive impact on the probability of the failure of the rural banks/islamic rural banks, while the compliance on the premium amount variable $\left(X_{3}\right)$ has negative impact of the failure of the rural banks/islamic rural banks. According to the regression output, the logit equation model in predicting the failure of rural banks/islamic rural banks is:

$$
P_{\mathrm{i}}=\frac{1}{\left(1+e^{-\left(1.2037 X_{1}-0.7143 X_{3}+1.6783 X_{5}+2.0432 X_{6}+5.2748 X_{8}-6.0895\right)}\right)}
$$


whereas:

$P_{\mathrm{i}} \quad: \quad$ Probability of rural banks/Islamic rural banks failure.

$X_{1}$ : Duplication of roles of shareholders and directors.

$X_{3}$ : Bank compliance on premium payment in a correct amount.

$X_{5}$ : Incompleteness of responsibility letter submitted by directors.

$X_{6}:$ Incompleteness of responsibility letter submitted by commissioners.

$X_{8} \quad$ : Bank was classified as the bank in the special supervision.

Table 6. Logit Model

\begin{tabular}{ccccc}
\hline Variable & Coefficient & Std. Error & z-Statistic & Prob. \\
\hline$X_{1}$ & 1.203717 & 0.432052 & 2.786049 & 0.0053 \\
$X_{3}$ & -0.714321 & 0.334678 & -2.134353 & 0.0328 \\
$X_{5}$ & 1.678294 & 0.507054 & 3.309895 & 0.0009 \\
$X_{6}$ & 2.043192 & 0.458608 & 4.455201 & 0.0000 \\
$X_{8}$ & 5.274790 & 0.464790 & 11.34877 & 0.0000 \\
C & -6.089469 & 0.460930 & -13.21127 & 0.0000 \\
\hline McFadden R-squared & 0.632485 & Mean dependent var & 0.047520 \\
S.D. dependent var & 0.212803 & S.E. of regression & 0.145375 \\
Akaike in-fo criterion & 0.146765 & Sum squared resid & 40.34475 \\
Schwarz criterion & 0.164177 & Log likelihood & -134.5270 \\
Hannan-Quinn criter. & 0.153172 & Deviance & 269.0541 \\
Restr. Deviance & 732.0892 & Restr. log likelihood & -366.0446 \\
LR statistic & 463.0351 & Avg. log likelihood & -0.070249 \\
Prob(LR statistic) & 0.000000 & & Total obs & 1915 \\
\hline Obs with Dep=0 & 1824 & & \\
Obs with Dep=1 & 91 & & \\
\hline
\end{tabular}

\subsection{Result of Analysis}

\section{Significance Test}

Likelihood Ratio (LR) test was done to find out whether the independent variables which were used at the same time have an impact on the dependent variables or not. In default $\mathrm{H} 0$ used was that the independent variables have no impact on the dependent variables, and $\mathrm{H} 1$ was that at least one independent variable affects the dependent variables. The test was done with an LR Stat probability value of alpha $5 \%$. Based on the e-views test as in the above, the LR Prob is equal to 0.000 , far smaller than the alpha $5 \%$, hence the likelihood test suggested to reject the $\mathrm{H} 0$ and accept $\mathrm{H} 1$, which means in overall with LR Prob reaching 0, the model rejects the hypotheses 0 which indicates no impact of the independent variables to the dependent variables. In other view, at least one independent variable can have an impact to the dependent variables.

\section{Partial Test (Coefficient Significance)}

The significance perspectives on the six variables (including the intercept) used, all variables show a significance with an inaccuracy probability of 0 or close to 0 . It shows that all variables have an impact on the probability of rural banks/islamic rural banks failure. Another interesting idea from this research is that the consistency of impact direction resulted from each variable. Variables such as role duplication of shareholders and directors $\left(X_{1}\right)$, incompleteness of responsibility letter submitted by directors $\left(X_{5}\right)$, incompleteness of responsibility letter submitted by commissioners $\left(X_{6}\right)$, and bank was classified as the bank in the special supervision $\left(X_{8}\right)$ have a positive impact on the probability of rural banks/islamic rural banks failure, while the compliance to premium amount variable has a negative impact on the failure of rural banks/islamic rural banks.

\section{Determination}

From the perspective of the determination equation, it shows a significant level of determination with the value of mc-Faden $r$ squared closes to $63 \%$. The amount is substantial for a logistic equation, where it shows the level of determination of the model to dependent variables is about $63 \%$. 


\section{Fit/Merit model}

With an AIC of 0,146765 and SC of 0,164177, which were smaller than 1, it can be said that the model is fit for predicting the dependent variables.

\subsection{Determination of Cut off Probability}

Cut off Probability was established by using the iteration process to maximize the successful level by minimizing the error level. Each output is considered true when and only when:

1. The model probability $\geq$ cut off and banks are failed; and

2. The model probability < cut off, and banks are not failed.

In relation to error, there are two types of error that may occur, i.e. error type 1 when a model predicts the failure of rural banks/Islamic rural banks, but it did not fail, or error type 2 when the model predicts there will be no rural banks/Islamic rural banks failure, but they were failed. The search of an optimum cut off point will be done by maximizing the successful probability of the predictor model altogether with minimizing the total error (error type 1 and error type 2). Assuming:

Total of successful prediction $\quad=n$

Total of error type $1 \quad=\mathrm{m}$

Total of error type $2=0$

Optimum cut off $\quad=p$

Then the value of an optimum cut off will be found in the following combination:

$$
p=\max =\frac{n}{(m+o)}
$$

The search of an optimum cut off value was done by iteration process on the cut off prediction. Taking into account that the cut off will be done to the probability figure, the value of optimum cut off will be within the interval of $0-1(0 \%-100 \%)$. The iteration is done by using the 200 probabilities of cut off value of 0 at the smallest value and $99.5 \%$ at the highest value with a step of $0.005(0.5 \%)$ on each iteration.

Using the formula mentioned above, the $p$ value can be obtained for each probability (200 probabilities). In Figure 3, the X-axis shows the probability level starting from $0 \%$ up to $99.5 \%$. The Y-axis shows the results of $p$ values from each probability. The higher $p$ value so the more optimal cut off probability. This is because the $p$ value shows the comparison between the number of successful predictions and the number of errors. At the point where the highest $\mathrm{p}$ value is obtained, the $p$ value is the optimal cut off probability. The following is the graph of the result of iteration.

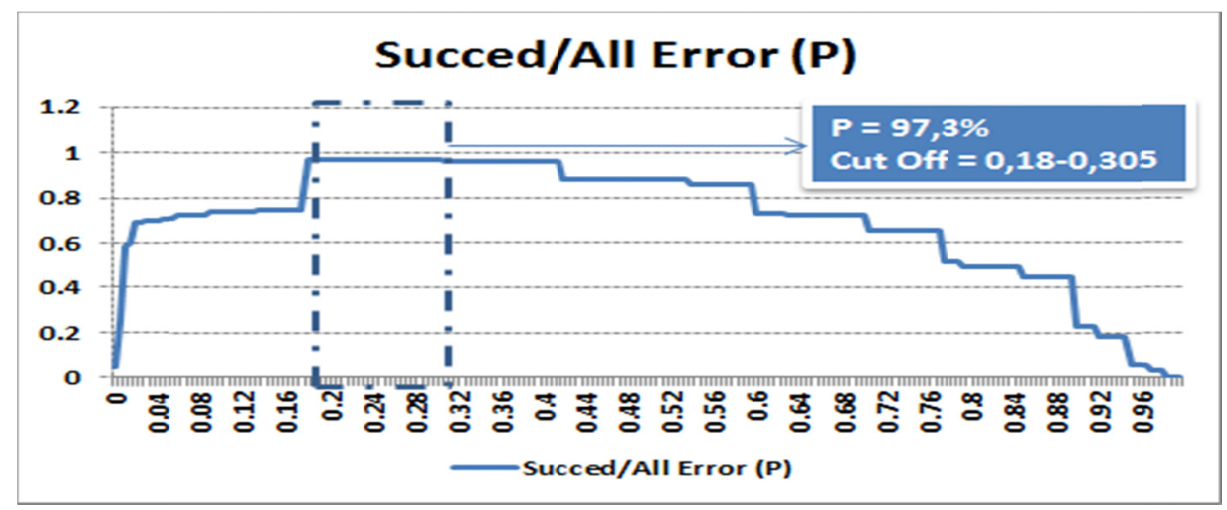

Figure 3. Result of Iteration of Cut off Probability

From Figure 3, it can be seen that the cut off is of $18 \%-30.5 \%$ contributed to the same p-value of $97.3 \%$. As the objective of the research is to establish an early warning indicator, the sensitivity of analysing tools is essential. Therefore, the cut off that will be used is $18 \%$. Based on the result of the analysis, it can be concluded that when using the cut off of $18 \%$,

1. The model can predict $73(80 \%)$ data of liquidated banks of 91 total liquidated banks;

2. Total error (error type $1+$ error type 2 ) that were created was 75 of 1915 data or around 3,9\%. 


\subsection{Odd Ratio}

Odd ratios for each variable can be calculated by:

$$
\text { Odd Ratio } X_{i}=e^{b_{i} X_{i}}
$$

whereas:

Odd Ratio $X_{i}=$ Odd Ratio Variable $X_{i}$

$b_{i}=$ Coefficient $X_{i}$

Based on the calculation of the formula it is known that the odds ratios for each variable are as follows:

Table 7. Odd Ratio

\begin{tabular}{cccccc}
\hline $\mathrm{C}$ & $X_{1}$ & $X_{3}$ & $X_{5}$ & $X_{6}$ & $X_{8}$ \\
\hline 0.002 & 3.332 & 0.490 & 5.356 & 7.715 & 195.349 \\
\hline
\end{tabular}

whereas:

$X_{1} \quad$ : Duplication of roles of shareholders and directors

$X_{3} \quad$ : Bank compliance on premium payment in an accurate amount

$X_{5} \quad$ : Incompleteness of responsibility letter submitted by directors

$X_{6} \quad$ : Incompleteness of responsibility letter submitted by commissioners

$X_{8} \quad$ : Bank was classified as bank in special supervision.

With the odd ratio above, it can be interpreted as follows:

1. Bank's opportunities, which are incomplete the letter of responsibilities from the commissioners to become a failed bank increases by 7.72 times compared to the bank whose complete of responsibilities letter from controlling shareholder.

2. Bank's opportunities, which are incomplete the letter of responsibilities from directors to become failed bank increases 5.36 times compared to the bank whose the responsibilities letter from directors, is complete.

3. Bank's opportunities with duplication role of shareholders and directors to become failed banks increased by 3.33 times compared to banks that did not have a duplication role of shareholders and directors.

4. Bank's opportunities that do not comply with paying the premium in the correct amount to become a bank failure increases by 0.49 times from the obedient bank to pay the premium in the correct amount.

5. Opportunities for banks with special supervision status to become failed banks increase 195.35 times compared to banks that are not in special supervision status. This can be understood because to become a failed bank, and the bank must be paced in special supervision.

\subsection{Evaluation of Model}

Besides conducting the model evaluation statistically, the researchers also had evaluated on the output of the prediction model versus actual data. The evaluation was done by taking into account all value probabilities of five variables and made a comparison with the output of the prediction model to the actual data. With a probability value of each variables ranging between 1 or 0 ( 2 probabilities), so there will be 32 combinations.

$$
T C=2 ! * 2 ! * 2 ! * 2 ! * 2 !=32
$$

whereas:

\section{$T C$ : Total Combination}

Combination and calculation of probability is done in excel software which created the following table of probability:

Table 8. Result of Evaluation of Model with Actual Data

\begin{tabular}{cccccccc}
\hline Combination & $X_{1}$ & $X_{3}$ & $X_{5}$ & $X_{6}$ & $X_{8}$ & Prob & Cut off \\
\hline 1 & 0 & 0 & 0 & 0 & 0 & 0.002261 & No \\
2 & 0 & 1 & 0 & 0 & 0 & 0.001108 & No \\
3 & 0 & 0 & 0 & 1 & 0 & 0.017187 & No \\
\hline
\end{tabular}




\begin{tabular}{llllllll}
\hline 4 & 0 & 1 & 0 & 1 & 0 & 0.008488 & No \\
5 & 0 & 0 & 1 & 0 & 0 & 0.011995 & No \\
6 & 0 & 1 & 1 & 0 & 0 & 0.005908 & No \\
7 & 0 & 0 & 1 & 1 & 0 & 0.085647 & No \\
8 & 0 & 1 & 1 & 1 & 0 & 0.043843 & No \\
9 & 1 & 0 & 0 & 0 & 0 & 0.007497 & No \\
10 & 1 & 1 & 0 & 0 & 0 & 0.003684 & No \\
11 & 1 & 0 & 0 & 1 & 0 & 0.055067 & No \\
12 & 1 & 1 & 0 & 1 & 0 & 0.027736 & No \\
13 & 1 & 0 & 1 & 0 & 0 & 0.038886 & No \\
14 & 1 & 1 & 1 & 0 & 0 & 0.019421 & Yes \\
15 & 1 & 0 & 1 & 1 & 0 & 0.237893 & No \\
16 & 1 & 1 & 1 & 1 & 0 & 0.132551 & Yes \\
17 & 0 & 0 & 0 & 0 & 1 & 0.306894 & No \\
18 & 0 & 1 & 0 & 0 & 1 & 0.17814 & Yes \\
19 & 0 & 0 & 0 & 1 & 1 & 0.773558 & Yes \\
20 & 0 & 1 & 0 & 1 & 1 & 0.625789 & Yes \\
21 & 0 & 0 & 1 & 0 & 1 & 0.703415 & Yes \\
22 & 0 & 1 & 1 & 0 & 1 & 0.537254 & Yes \\
23 & 0 & 0 & 1 & 1 & 1 & 0.948182 & Yes \\
24 & 0 & 1 & 1 & 1 & 1 & 0.899573 & Yes \\
25 & 1 & 0 & 0 & 0 & 1 & 0.596051 & Yes \\
26 & 1 & 1 & 0 & 0 & 1 & 0.419389 & Yes \\
27 & 1 & 0 & 0 & 1 & 1 & 0.919252 & Yes \\
28 & 1 & 1 & 0 & 1 & 1 & 0.847859 & 0.887687 \\
29 & 1 & 0 & 1 & 0 & 1 & 0.794621 & 0.983865 \\
30 & 1 & 1 & 1 & 0 & 1 & 0.967586 & \\
31 & 1 & 0 & 1 & 1 & 1 & 1 & \\
32 & 1 & 1 & 1 & 1 & $0 s$ & \\
\hline
\end{tabular}

Table 8 shows that 32 combinations that were created, 16 of them had given a probability value $\geq$ cut off $(18 \%)$. In order to evaluate the output, the 16 combinations of the value of independent variables were compared to the actual data.

Table 9. Comparison of Probability Based on Model and Actual Data

\begin{tabular}{ccccccccccc}
\hline Combination & $X_{I}$ & $X_{3}$ & $X_{5}$ & $X_{6}$ & $X_{8}$ & $\begin{array}{c}\text { Total } \\
\text { Identification }\end{array}$ & $\begin{array}{c}\text { Total Successful } \\
\text { Identification }\end{array}$ & $\begin{array}{c}\text { Model-based } \\
\text { Probability }\end{array}$ & $\begin{array}{c}\text { Actual Data-based } \\
\text { Probability }\end{array}$ \\
\hline 1 & 0 & 0 & 0 & 0 & 1 & 54 & 18 & 0.306894 & 0.333333 \\
2 & 0 & 1 & 0 & 1 & 1 & 6 & 2 & 0.625789 & 0.333333 \\
3 & 0 & 1 & 1 & 0 & 1 & 5 & 2 & 0.537254 & 0.4 \\
4 & 1 & 1 & 0 & 0 & 1 & 7 & 4 & 0.419389 & 0.571429 \\
5 & 0 & 0 & 1 & 0 & 1 & 5 & 3 & 0.703415 & 0.6 \\
6 & 1 & 0 & 0 & 0 & 1 & 10 & 6 & 0.596051 & 0.6 \\
7 & 0 & 0 & 0 & 1 & 1 & 8 & 6 & 0.773558 & 0.75 \\
8 & 0 & 1 & 1 & 1 & 1 & 15 & 12 & 0.899573 & 0.8 \\
1 & 0 & 0 & 1 & 1 & 1 & 9 & 9 & 0.948182 & 1 \\
11 & 1 & 0 & 0 & 1 & 1 & 3 & 3 & 0.919252 & 1 \\
12 & 1 & 1 & 0 & 1 & 1 & 2 & 2 & 0.847859 & 1 \\
13 & 1 & 1 & 1 & 0 & 1 & 1 & 1 & 0.794621 & 1 \\
\hline
\end{tabular}


Refer Table 9, it can be summarized that:

1. From 16 combinations of the value of independent variables, only 14 combinations can produce a higher probability value than the cut-off.

2. The 14 combinations of independent variables that we're able to create a probability value higher than the cut off can indicate a failure probability for as many as 130 times.

3. From 130 signals that had been created, 73 rural banks/islamic rural banks were truly followed by the failure of the banks.

Moreover, Table 9 also shows that when the probability model provided value over $90 \%$; in reality, all banks indicated as the failed bank will experience a failure (100\%). In addition to that, the probability of bank failure is in line with model identification when a model indicates a failure more than $70 \%$, in which the $70 \%$ of the predicted banks by the model were truly failed. Indication of bank failure when the model indicates a failure probability of above $50 \%$ and under $60 \%$ tends to be mixed, wherein several positions of model tended to be overestimated, and some of the model positions were underestimated, but in overall the model produced a linear result with the data. Further failure probability indication can be overestimated when the failure probability identified by the model is under $50 \%$.

\subsection{The Use of Model as Early Warning Indicator}

By comparing the output model with actual data, the above logit indicator can be developed into an early warning tool with the following classification:
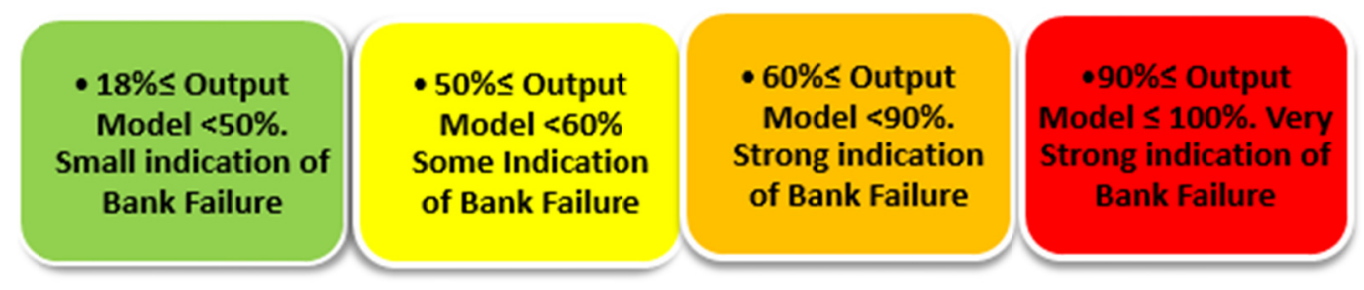

$\begin{array}{ll}\text { Green } & \text { : Few indications of bank failure } \\ \text { Yellow } & : \text { There is an indication of bank failure } \\ \text { Orange } & \text { : Strong indication of bank failure } \\ \text { Red } & \text { : A very strong indication of bank failure }\end{array}$

If the model creates the rural banks/Islamic rural banks failure probability of around $18 \% \leq 50 \%$, it shows that there are few indications of failing banks. IDIC should begin the analysis to identify the weakness of bank governance. When the model shows the level of failure probability between $\geq 50 \%$ and $<60 \%$, the level of rural banks/Islamic rural banks failure is higher. So, in that particular condition, IDIC shall conduct an examination to find out the financial soundness condition of the bank. For that purpose, IDIC has to prepare the necessary resources and funding to anticipate the failure of rural banks/islamic rural banks. Moreover, when the model shows the level of failure probability of more than $90 \%$, the bank has a strong indication that it will fail. At this moment, there is not much that can be done by IDIC other than preparing for the moment the IFSA hands over the rural banks/islamic rural banks.

\section{Conclusion and Recommendation}

\subsection{Conclusion}

According to this research, it can be concluded that:

1. The failure of rural banks/islamic rural banks in Indonesia is caused by the fraud done by the owners, management, and/or employee of the bank. Before the fraud is found by the bank supervisors, the financial report can't reflect the real financial condition. Hence, the financial ratios derived from the report, such as the CAR can't well-describe the real condition.

2. The test result on variables that are proxies of the weakness of governance implementation that positively impacts the probability of rural banks/islamic rural banks failure such as (1) the submission of incomplete the responsibility letter by the commissioners and directors of rural banks/islamic rural banks; (2) duplication of roles of shareholders and boards of rural banks/islamic rural banks; (3) duplication of roles 
of shareholders and directors of rural banks/islamic rural banks; (4) the condition of rural banks/islamic rural banks status whether it has been previously classified as in special supervision. Meanwhile, another variable which is the compliance level of rural banks/islamic rural banks in the payment of premium to IDIC in the correct amount has been defined to have a negative impact to the probability of rural banks/islamic rural banks failure.

\subsection{Recommendation}

Based on this research, we would like to suggest the following recommendations:

1. The establishment of policy on the prohibition of roles duplication for shareholders and directors of rural banks/islamic rural banks;

2. Dismissing the exception for rural banks/islamic rural banks that are currently exempted their financial report to be audited by the public accountant;

3. Applying a sanction for controlling shareholders/directors of rural banks/islamic rural banks who did not submit the responsibility letter to IDIC on (i) commitment and willingness to comply with all regulations as stipulated in the IDIC regulations; (ii) willingness to behold responsible personally on the negligence or the Law violating acts that caused a loss to the bank or threatening the business of the bank; (iii) willingness to release and hand over all rights, ownership, management, and/or interests in the event of failed bank and decided to be rescued or liquidated; and

4. Improvement of supervision by IFSA with more focus on the GCG implementation.

\section{Acknowledgements}

The author would like to express his gratitude and highest appreciation to all those who assisted the author in completing this paper as one of the requirements for completing a doctoral program at the IPB University (Bogor Agricultural University). In particular, the authors thank the leaders of IDIC who provided scholarships to the authors to continue their studies in this doctoral program.

\section{References}

Altman, E. I. (1968). Financial ratios, discriminant analysis and the prediction of corporate bankruptcy. The Journal of Finance, 23(4), 589-609. https://doi.org/10.2307/2978933.

Anggriningrum, D. P., Hendikawati, P., \& Abidin, Z. (2013). Comparison of stock price predictions using backpropagation and arima artificial neural networks. Unnes Journal of Mathematics, 2(2), 104-109. (in Bahasa). https://doi.org/10.15294/ujm.v6i1.11681

Arbaina, S. E. (2012). Implementation of Good Corporate Governance on Banking Industries in Indonesia. UNESA Accounting Journal, 1(1), 1-18. (in Bahasa)

Bani, M., Zadehbagher, M., \& Saberimanesh, J. J. M. A. (2014). Prediction of bank failures based on zmisky and toffler models in the banking industry or Iran. Kuwait Chapter of the Arabian Journal of Business and Management Review, 3(12), 142-152. https://doi.org/10.12816/0018813

Bashir, A., Javed, A., \& Iqbal, S. (2015). Business failures predication Karachi stock exchange. Indian Journal of Management Science, 5(1), 74-82.

Beaver, W. H. (1966). Financial ratios as predictors of failure. Empirical Research in Accounting: Selected Studies, 4, 71-102.

Calabrese, R., \& Guidici, P. (2015). Estimating bank default with generalised extreme value regression models. The Journal of the Operational Research Society, 66(11), 1783-1792. https://doi.org/10.1057/jors.2014.106.

Chuvakhin, N., \& Gertmenian, L. (2003). Predicting Bankruptcy in the WorldCom Age. Retrieved July, 20, 2019 from http://ncbase.com/papers/BP.pdf

Cole, R. A., \& White, L. J. (2012). Déjà vu all over again: The causes of U.S. commercial bank failures this time around. Journal of Financial Service Research, 42(1-2), 5-29. https://doi.org/10.1007/s10693-011-0116-9

Ekinci, A., \& Erdal, H. I. (2016). Forecasting bank failure: Base learners, ensembles and hybrid ensembles. Computational Economics, 49(4), 677-686. https://doi.org/10.1007/s10614-016-9623-y

Jan, A., \& Marimuthu, M. (2016). Bankruptcy profile of foreign vs. domestic Islamic banks of Malayis: A post crisis period analysis. International Journal of Economics and Financial Issues, 6(1), 332-346.

Kaminsky, G. L., \& Carmen, R. (1999). The Twin Crises: The Causes of Banking and Balance-of-Payments 
Problems. American Economic Review, 89(3), 473-500.

Konstituanto, A. (2012). The probability of bank failure from the management and financial aspects. Bogor (ID): Bogor Agriculturan University. (in Bahasa)

Outtecheva, N. (2007). Corporate financial distress: An empirical analysis of distress risk. Swiss (EU): University of St.Gallen.

Ozili, P. K. (2017). Bank earnings management and income smoothing using commission and fee income. International Journal of Managerial $\quad$ Finance, $\quad 13(4), \quad 419-439$. https://doi.org/10.1108/JAAR-02-2018-0030

Pranowo, K. et al. (2010). Determinant of Corporate Financial Distress in an Emerging Market Economy: Empirical Evidence from the Indonesian Stock Exchange 2004-2008. International Research Journal of Finance and Economics, (52), 80-88. (in Bahasa).

Rosa, P. S., \& Gartner, I. R. (2017). Financial distress in Brazilian banks: Early warning model. Revista Contabilidade \& Financas, 29(77), 312-331. https://doi.org/10.1590/1808-057x201803910

Slefendorfas, G. (2016). Bankruptcy prediction model for private limited companies of Lithuania. EKONOMIKA, 95(1), 134-152. https://doi.org/10.15388/Ekon.2016.1.9910

Yusdiana, K. (2014). Altman's z-score and CAMEL Model Analysis to Predict Bank Failure (Case Study on Listed Commercial Bank in Indonesia Stock Exchange, 2007-2011) (in Bahasa). Business Management Journal, 6(1), 85-92.

Wibowo, B. (2017). Methods of measuring the probability of bankruptcy of a bank and analyzing its relationship with diversification of income sources: The case of Indonesian banking. Entrepreneurship, Business, and Strategic Journal, 11(1), 52-66. https://doi.org/10.24843/MATRIK:JMBK.2017.V11.i01.p05. (in Bahasa).

Wilopo. (2006). Analysis of the factors that influence the tendency of accounting fraud. Accounting National Symposium IX (in Bahasa). Padang-West Sumatera, 23-26 August 2006.

\section{Copyrights}

Copyright for this article is retained by the author(s), with first publication rights granted to the journal.

This is an open-access article distributed under the terms and conditions of the Creative Commons Attribution license (http://creativecommons.org/licenses/by/4.0/). 